\title{
LSSP-PCR of Trypanosoma cruzi: how the single primer sequence affects the kDNA signature
}

\author{
Marcela Segatto ', Claudiney Melquíades Rodrigues', Carlos Renato Machado', Glória Regina Franco', \\ Sérgio Danilo Junho Pena ${ }^{1}$ and Andréa Mara Macedo ${ }^{1,2^{*}}$
}

\begin{abstract}
Background: Low-stringency single specific primer PCR (LSSP-PCR) is a highly sensitive and discriminating technique that has been extensively used to genetically characterize Trypanosoma cruzi populations in the presence of large amounts of host DNA. To ensure high sensitivity, in most $T$. cruzi studies, the variable regions of the naturally amplified kinetoplast DNA (kDNA) minicircles were targeted, and this method translated the intraspecific polymorphisms of these molecules into specific and reproducible kDNA signatures. Although the LSSP-PCR technique is reproducible under strict assay conditions, the complex banding pattern generated can be significantly altered by even a single-base change in the target DNA. Our survey of the literature identified eight different primers with similar, if not identical, names that have been used for kDNA amplification and LSSP-PCR of T. cruzi. Although different primer sequences were used in these studies, many of the authors cited the same reference report to justify their primer choice. We wondered whether these changes in the primer sequence could affect also the parasite LSSP-PCR profiles.
\end{abstract}

Findings: To answer this question we compared the kDNA signatures obtained from three different and extensively studied T. cruzi populations with the eight primers found in the literature. Our results clearly demonstrate that even minimal modifications in the oligonucleotide sequences, especially in the $3^{\prime}$ or $5^{\prime}$ end, can significantly change the kDNA signature of a T. cruzi strain.

Conclusions: These results highlight the necessity of careful preservation of primer nomenclature and sequence when reproducing an LSSP-PCR work to avoid confusion and allow comparison of results among different laboratories.

Keywords: LSSP-PCR, Trypanosoma cruzi, kDNA signatures, Genetic diversity

\section{Introduction}

Chagas disease is caused by the protozoan Trypanosoma cruzi and has a variable clinical course ranging from symptomless infection to severe chronic disease with cardiovascular and/or gastrointestinal involvement. The factors influencing this clinical variability have not yet been elucidated, but both host and parasite genetic factors are likely important.

\footnotetext{
* Correspondence: andrea@icb.ufmg.br

'Departamento de Bioquímica e Imunologia, Instituto de Ciências Biológicas, Universidade Federal de Minas Gerais, Belo Horizonte, Minas Gerais, Brazil ${ }^{2}$ Laboratório de Genética Bioquímica, Departamento de Bioquímica e Imunologia, Instituto de Ciências Biológicas, Universidade Federal de Minas Gerais, Avenida Antônio Carlos, 6627 - Bloco K4, sala 245 - ICB/UFMG Bairro São Luiz, Belo Horizonte, Minas Gerais CEP 31270-901, Brazil
}

The biological, biochemical, and genetic diversity of $T$. cruzi strains have long been recognized, and over the years, numerous approaches have been used to characterize the parasites, such as multilocus enzyme electrophoresis (MLEE) [1,2], kinetoplast DNA restriction fragment length polymorphisms (kDNA RFLP) [3], random amplified polymorphic DNA (RAPD) [4-6], lowstringency single specific primer PCR (LSSP-PCR) [7], multilocus microsatellite typing (MLMT) [8-11], and many other methods such as PCR of the mini-exon and rDNA genes $[12,13]$.

The extensive efforts to comprehend the intraspecific genetic polymorphisms and population structure of $T$. cruzi are justified by the correlation between genetic variation and the biological properties of the parasite, including geographical distribution, host specificity, and

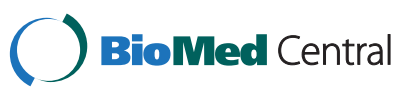


the clinical outcome of infection. Additional understanding of the relationship between $T$. cruzi variation and clinical outcome will likely lead to a better understanding of the molecular epidemiology of Chagas disease [14-16].

In this context, LSSP-PCR targeting the sequence polymorphisms within the variable regions of $T$. cruzi $\mathrm{kDNA}$ [17-21] or the intergenic regions of the spliced-leader gene [22] allows direct profiling of the parasites present in the tissues of chronically infected patients [21,23].

LSSP-PCR is an extremely simple, PCR-based technique that permits the detection of single or multiple mutations in gene-sized DNA fragments. Briefly, purified DNA fragments are subjected to PCR using high concentrations of a single specific oligonucleotide primer, large amounts of Taq DNA polymerase, and a very low annealing temperature. Under these conditions, the primer hybridizes specifically to its complementary region and nonspecifically to multiple sites within the DNA fragments in a sequence-dependent manner, producing a heterogeneous set of reaction products that constitutes a unique "gene signature profile" [24]. In fact, LSSP-PCR has been used in many organisms and fields of genetics and molecular medicine to obtain rapid, cheap and sensitive detection of mutations and sequence variations [25-33].

The first study to use LSSP-PCR on T. cruzi was performed by Vago and collaborators using a primer called S35 as a driver [21, 23]. This primer was originally designed to amplify minicircle variable region sequences of T. cruzi [34]. Many subsequent works cite these studies to justify the use of the chosen methodology, although the primer sequences published do not exactly match what was previously used. Although the LSSP-PCR technique is highly reproducible under strict conditions, the complex banding pattern obtained can be significantly altered by even a single-base change in the target DNA [24], which suggests that different primer sequences may also produce substantially different results.

Here, we surveyed the literature to catalogue the primer sequences used for $T$. cruzi kDNA analysis by LSSP-PCR and references cited by many research groups to assess the impact of the primer sequence on the parasite profiles. Our results clearly demonstrated that LSSPPCR is a sensible and reproducible profiling technique, but minimal modifications in the oligonucleotide sequences, used in the second round of PCR, can significantly change the kDNA signature of $T$. cruzi strains.

\section{Findings}

\section{Parasites and DNA extraction}

Three T. cruzi populations were used: the CL Brener clone ( $T$. cruzi VI), which was harvested from the CL strain isolated from a Triatoma infestans specimen; the
Col1.7G2 clone (T. cruzi I), which was obtained from the Colombian strain and originally isolated from the blood of a chronic cardiac patient in Colombia; and the JG strain (T. cruzi II), a monoclonal population isolated from a chagasic patient with megaesophagus in Minas Gerais, Brazil.

For T. cruzi DNA extraction, the epimastigote forms of each parasite population were grown in liver infusion tryptose (LIT) medium containing $10 \%$ calf serum at $27-28^{\circ} \mathrm{C}$. Once the culture contained $10^{8}$ epimastigote forms, the parasite cells were harvested, washed three times in sterile phosphate buffered saline and lysed in the presence of proteinase $\mathrm{K}$ overnight at $56^{\circ} \mathrm{C}$. Standard DNA extraction was performed with phenol/chloroform as previously described [35].

\section{Low-stringency single specific primer polymerase chain reaction (LSSP-PCR)}

The kDNA signatures were obtained using a two-step procedure. The first step consisted of the specific PCR amplification of fragments of approximately $330 \mathrm{bp}$ from variable regions of $T$. cruzi kDNA minicircle molecules. This reaction was carried out in a final volume of $20 \mu \mathrm{l}$ and contained $1.5 \mathrm{mM} \mathrm{MgCl}_{2}$, Green Go Taq Reaction Buffer pH 8.5 (Promega, Madison, Wisconsin, USA), $250 \mu \mathrm{M}$ dNTPs, primers 121 or S35 (5'-AAATAATG TACGGGKGAGATGCATGA-3') and 122 (5'-GGTTC GATTGGGGTTGGTGTAATATA-3') at $1.0 \mu \mathrm{M}, 1.0 \mathrm{U}$ of Go Taq DNA Polymerase (Promega) and $1.0 \mathrm{ng}$ of purified DNA template. Amplification was performed in a PT100 thermocycler (MJ Research) using an initial denaturation step at $94^{\circ} \mathrm{C}$ for $5 \mathrm{~min}$ followed by $35 \mathrm{amp}$ lification cycles of an annealing step at $60^{\circ} \mathrm{C}$, extension at $72^{\circ} \mathrm{C}$ and denaturation at $94^{\circ} \mathrm{C}$, each for $1 \mathrm{~min}$. The final extension step was extended to $10 \mathrm{~min}$. Five microliters of PCR products was visualized on a silver-stained $6 \%$ polyacrylamide gel as previously described [36].

The remaining $15 \mu \mathrm{L}$ of the PCR reaction was then subjected to electrophoresis on an ethidium bromidestained $1.5 \%$ agarose gel (1.0\% agarose, $0.5 \%$ low melting point agarose). The kDNA amplicons were excised from the gel, diluted 10-fold in sterile Milli-Q water and submitted to a second step of low-stringency amplification using a single primer (LSSP-PCR) (Table 1). This second PCR was carried out in a final volume of $10 \mu \mathrm{l}$ and contained $1.5 \mathrm{mM} \mathrm{MgCl}$, Colorless Go Taq Reaction Buffer pH 8.5 (Promega), dNTPs at $250 \mu \mathrm{M}$, primer at $4.5 \mathrm{mM}, 1.6 \mathrm{U}$ of Go Taq DNA Polymerase (Promega) and $1.0 \mu \mathrm{l}$ of a solution containing the approximately 330 bp DNA fragments prepared as described above. Amplification was performed in a PT100 thermocycler (MJ Research) as follows: an initial denaturation step at $94^{\circ} \mathrm{C}$ for $5 \mathrm{~min}$, followed by 40 amplification cycles of: an annealing step at $30^{\circ} \mathrm{C}$, extension step at $72^{\circ} \mathrm{C}$, and 
Table 1 Sequence of primers designed to analyze three T. cruzi populations by LSSP-PCR

\begin{tabular}{|c|c|c|c|c|}
\hline $\begin{array}{l}\text { Primer } \\
\text { code }\end{array}$ & $\begin{array}{l}\text { Original } \\
\text { name }\end{array}$ & Sequence $\left(5^{\prime} \rightarrow 3^{\prime}\right)$ & $\begin{array}{l}\text { Size } \\
\text { (bp) }\end{array}$ & Reference \\
\hline & & 26 & & \\
\hline C & S35 & AAATAATGTACGGGKGAGATGCATGA & 26 & {$[20,22,34,40]$} \\
\hline A & S35 & -ATAATGTACGGGKGAGATGC-— & 20 & {$[42]$} \\
\hline B & S35 & AAATAATGTACGGG-GAGATGCATGA & 25 & {$[23,43-45]$} \\
\hline D & S35 & AAATAATGTACGGGGGAGATGCATGA & 26 & {$[7,21]$} \\
\hline E & S35G & ——ATGTACGGG-GAGATGCATGA & 20 & {$[17,35,46]$} \\
\hline $\mathbf{F}$ & S35G* & ——ATGTACGGGGGAGATGCATGA & 21 & [19] \\
\hline G & S35G & AAATAATGTACGGGGGAGATG-—— & 21 & {$[41,47]$} \\
\hline $\mathrm{H}$ & S35G 5 & AAATAATGTACGGGGGAGAT_-—— & 20 & Not published \\
\hline
\end{tabular}

*Indicates that this primer was originally described as fluorescein labeled but here the fluorescent marker was removed. All changes relative to primer S35 described by Sturm et al. (primer C) are highlighted.

denaturation step at $94^{\circ} \mathrm{C}$, each for $1 \mathrm{~min}$. The final extension step was extended to $10 \mathrm{~min}$. LSSP-PCR products were also visualized on a silver-stained $6 \%$ polyacrylamide gel.

\section{Data analysis}

LSSP-PCR reactions were performed in triplicate, and only the consistent bands were taken into account to build a reproducible profile of each T. cruzi population. The multiband profiles obtained by LSSP-PCR of the $T$. cruzi populations were scored by eye, and each amplification band was numbered as present (1) or absent (0). These data were recorded on DNA-POP software [37], which calculates the proportion of shared bands among samples. Additionally, the distances among the profiles obtained with the different primers were calculated using the Nei and Li coefficient [38]. Phylogenetic trees were constructed based on genetic distance matrices obtained through UPGMA or primer sequences using the Treecon software program version 1.3b [39].

\section{Results}

The $330 \mathrm{bp}$ band corresponding to the variable region of kDNA minicircle molecules was successfully amplified

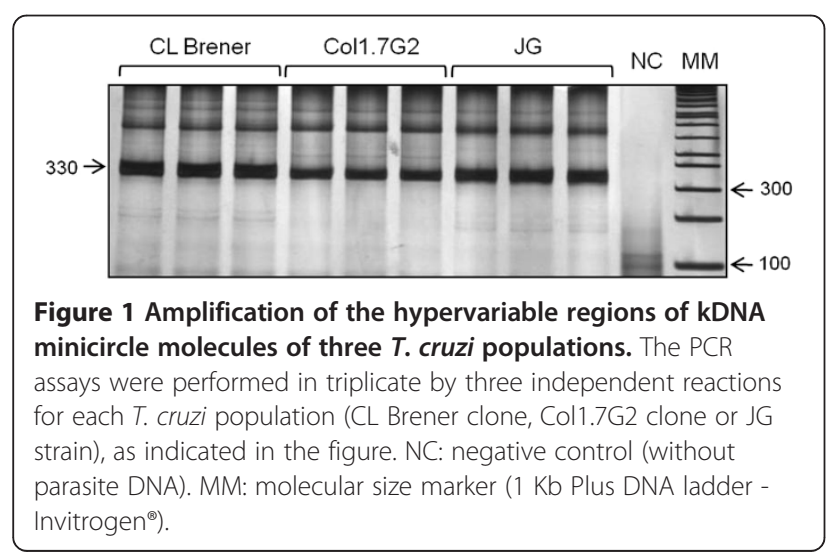

in all analyzed stocks (Figure 1). These amplicons were used as the templates for the second PCR reaction with different single primers to observe the influence of primer sequence on the kDNA signatures.

The LSSP-PCR profiles were reproducible in the evaluated banding range of 100-400 bp (Figure 2) and showed high inter-strain genetic variability among the three T. cruzi analyzed stocks, with clear, distinct patterns for each strain that were independent of the primer used (Figure 3). However, the multiband profiles of each strain obtained with the eight different primers resulted mostly in different kDNA signatures, although there was minimal sequence variation observed for some primers (Figure 3).

We further investigated whether the LSSP-PCR profiles produced were more similar when the primer

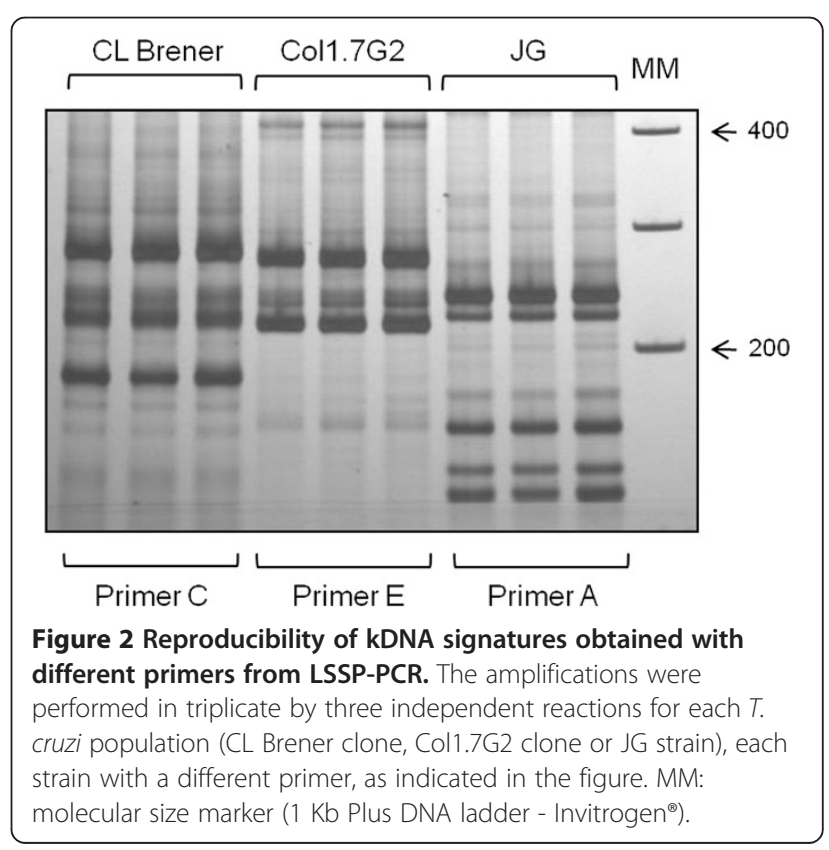




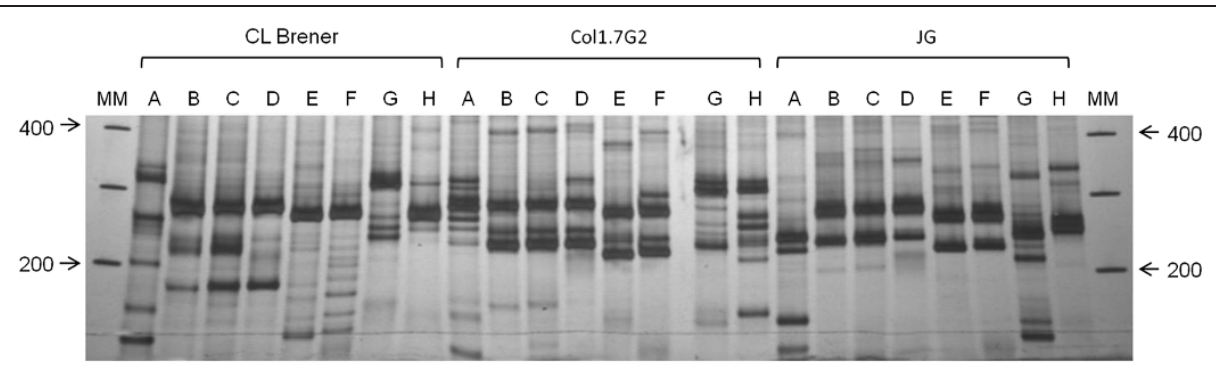

Figure 3 Evaluation of the genetic variability among three $T$. cruzi populations by LSSP-PCR with different primers. The primer used $(A$ to $H)$ is indicated below the profiles. MM: molecular size marker (1 Kb Plus DNA ladder - Invitrogen ${ }^{\oplus}$ ).

sequences were more similar. A phenotypic tree was constructed using the presence or absence of bands in the LSSP-PCR profiles as the distance matrix and the topology was compared with another tree constructed using the primer sequence data (Figure 4 and Table 1). As shown in Figure 4, there was not a general match between the trees' topologies. For some of the primers (e.g., primers $\mathrm{B}, \mathrm{C}$ and $\mathrm{D}$ ) there was a correlation between the similarity of the LSSP-PCR profiles generated and the primer sequence similarities. However, this was not observed for other more heterogeneous primers, suggesting that the position of nucleotide substitutions or insertions/deletions may have a strong influence on the profiles. In this aspect, as expected, small differences in the $3^{\prime}$ region, such as the single deletion between primers $\mathrm{G}$ and $\mathrm{H}$, caused dramatic changes in the LSSPPCR profiles. However, unlike for conventional PCR, alterations in the $5^{\prime}$ region of the primers (e.g., primers $\mathrm{D}$ and F) also strongly affected the LSSP-PCR profiles (Table 1 and Figure 4). This was not observed for the primers $B$ and $\mathrm{D}$, where the deletion is located in a more central position of the primer sequences (15th nucleotide).

Finally, we used the median proportion of shared bands between the LSSP-PCR profiles derived from the different $T$. cruzi stocks to evaluate the ability of primers to distinguish different parasites. According to this analysis, the most discriminative primer was $\mathrm{F}$ generating an average of $24 \%$ shared bands among the three strains, whereas the less polymorphic was primer $\mathrm{G}$ with $48 \%$ of shared bands (Table 2).

\section{Discussion}

The application of LSSP-PCR to the characterization of the $330 \mathrm{bp}$ variable portion of kDNA minicircle molecules produces complex banding patterns that allow identification of clones and strains from cultures or experimentally infected tissues with good discriminatory capacity [21]. Furthermore, the large genetic diversity in kDNA signatures obtained confirms the applicability of this method to genetic characterization studies on naturally infected vectors and humans [40, 41]. Differential tissue distribution of diverse clones of $T$. cruzi have been demonstrated in infected mice [35] and humans $[7,23]$. LSSP-PCR is also useful to identify the differential distribution of T. cruzi populations associated with disease reactivation [18].

Despite being widely used for T. cruzi studies, LSSP-PCR reproducibility has been questioned due to its low-stringency nature. However, we have observed in our laboratory over our ten years of experience that LSSP-PCR patterns are highly reproducible even when the experiments are performed on separate days by different workers or when different thermocyclers and electrophoretic runs are used. To achieve this standardized amplification conditions both the enzyme and primer sources, and a good quality DNA at an adequate concentration must be consistently used [21]. Herein, we confirmed the high reproducibility of the technique by performing reactions at least three times on different days and obtaining highly stable profiles using different primers.
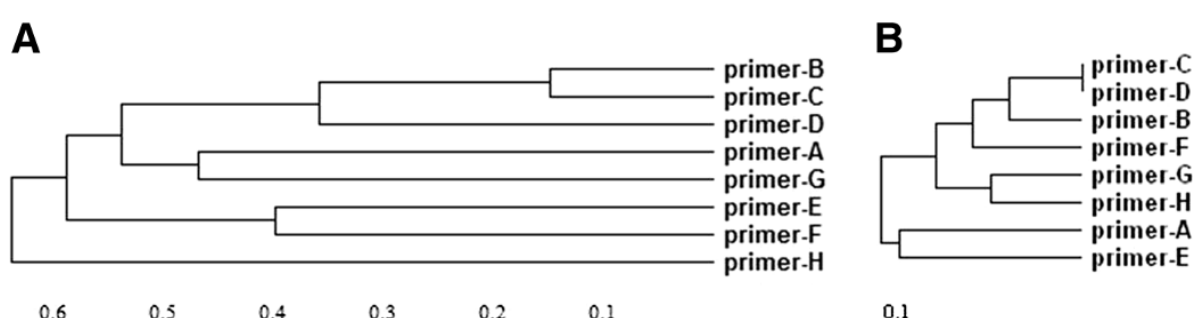

0.1

Figure 4 LSSP-PCR trees. (A) UPGMA tree generated from the distance of the LSSP-PCR profiles produced by each primer based on the sum of present and absent bands for the T. cruzi populations CL Brener, Col1.7G2 and JG. (B) Distance tree constructed from the primer sequences. 
Table 2 Average ratio of the proportion of shared bands among samples using the different primers

\begin{tabular}{ll}
\hline Primer & Mean proportion of shared bands \\
\hline primer A & 0.3909 \\
\hline primer B & 0.4050 \\
\hline primer C & 0.3882 \\
\hline primer D & 0.3401 \\
\hline primer E & 0.3945 \\
\hline primer F & 0.2364 \\
\hline primer G & 0.4873 \\
\hline primer H & 0.3176 \\
\hline mean & 0.3700 \\
\hline
\end{tabular}

LSSP-PCR uses a single primer that hybridizes with high specificity to its complementary sequence incorporated into the amplicons during the first round of PCR, and also with low specificity but in a sequencedependent manner to multiple sites within the amplified fragment during the second round. Thus the reaction yields a large number of products that can be resolved by electrophoresis to give rise to a multiband DNA fragment signature that reflects the DNA template sequence [24]. Changes as small as a single base mutation could drastically alter the multiband pattern, producing new signatures that are diagnostic of the specific alterations $[21,24]$. In this context, we asked whether the primer sequence might also influence the kDNA complex band in pattern.

To that end, we evaluated eight primer sequences previously used in the literature with similar names or citations. Our results demonstrated that sets of primers with related sequences, but differing from one another by 1 to 7 bases, resulted in different kDNA signatures for the same strain. In fact, alterations in primer sequence as small as a unique base mutation affected the kDNA multiband patterns, especially changes in the 3 'or $5^{\prime}$ regions.

On the other hand, when we analyzed the profiles obtained with the same primer for the three evaluated strains, we saw that they were completely different from one another despite of the primer used. This is extremely important since the main goal of LSSPPCR is to detect genetic polymorphisms in T. cruzi isolates belonging to distinct populations such as in different distant endemic areas or outbreaks or different clones within the same population with different tropisms, for example.

In conclusion we demonstrate here the importance of primer sequence when performing LSSP-PCR, at least for $T$. cruzi $\mathrm{kDNA}$. This is especially relevant because different researchers frequently reproduce published techniques, but if the primer sequences are not faithful, comparisons of LSSP-PCR results among laboratories are not feasible, contributing to the false idea that LSSPPCR is a technique poorly reproducible. Additionally, cases where oligonucleotide sequences are intentionally changed should be followed also by changes in the primers' names. This would be highly useful for all laboratories working on kDNA signatures, while avoiding confusion and improving the comparison of LSSP-PCR patterns among laboratories.

\section{Competing interests}

The authors declare that they have no competing interests.

\section{Authors' contributions}

MS processed the samples and experiments, analyzed data, reviewed the literature and wrote the manuscript. CMR processed the samples and experiments, analyzed data and reviewed the manuscript. CRM, GRF and SDJP analyzed data and reviewed the manuscript. AMM conceived of the study, and participated in its design and coordination and reviewed the manuscript. All authors read and approved the final manuscript.

\section{Acknowledgements}

This work was supported by FAPEMIG, CNPq (MCTI/CNPq/MS-SCTIE - Decit $N^{\circ}$ 40/2012) and CAPES founding agencies. We thank Neuza A. Rodrigues for expert technical assistance.

Received: 27 December 2012 Accepted: 25 April 2013 Published: 2 May 2013

\section{References}

1. Miles MA, Souza A, Povoa M, Shaw JJ, Lainson R, Toye PJ: Isozymic heterogeneity of Trypanosoma cruzi in the first autochthonous patients with Chagas' disease in Amazonian Brazil. Nature 1978, 272:819-821.

2. Miles MA, Toye PJ, Oswald SC, Godfrey DG: The identification by isoenzyme patterns of two distinct strain-groups of Trypanosoma cruzi, circulating independently in a rural area of Brazil. Trans $R$ Soc Trop Med Hyg 1977, 71:217-225.

3. Morel C, Simpson L: Characterization of pathogenic trypanosomatidae by restriction endonuclease fingerprinting of kinetoplast DNA minicircles. Am J Trop Med Hyg 1980, 29:1070-1074.

4. Dias Neto E, Steindel M, Passos LK, de Souza CP, Rollinson D, Katz N, Romanha AJ, Pena SD, Simpson AJ: The use of RAPDs for the study of the genetic diversity of Schistosoma mansoni and Trypanosoma cruzi. EXS 1993, 67:339-345.

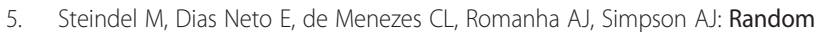
amplified polymorphic DNA analysis of Trypanosoma cruzi strains. Mol Biochem Parasitol 1993, 60:71-79.

6. Tibayrenc M, Neubauer K, Barnabe C, Guerrini F, Skarecky D, Ayala FJ: Genetic characterization of six parasitic protozoa: parity between random-primer DNA typing and multilocus enzyme electrophoresis. Proc Natl Acad Sci U S A 1993, 90:1335-1339.

7. Vago AR, Macedo AM, Adad SJ, Reis DD, Correa-Oliveira R: PCR detection of Trypanosoma cruzi DNA in oesophageal tissues of patients with chronic digestive Chagas' disease. Lancet 1996, 348:891-892.

8. Oliveira RP, Broude NE, Macedo AM, Cantor CR, Smith CL, Pena SD: Probing the genetic population structure of Trypanosoma cruzi with polymorphic microsatellites. Proc Natl Acad Sci U S A 1998, 95:3776-3780.

9. Oliveira RP, Melo Al, Macedo AM, Chiari E, Pena SD: The population structure of Trypanosoma cruzi: expanded analysis of 54 strains using eight polymorphic CA-repeat microsatellites. Mem Inst Oswaldo Cruz 1999, 94(Suppl 1):65-70.

10. Valadares HM, Pimenta JR, de Freitas JM, Duffy T, Bartholomeu DC, Oliveira Rde P, Chiari E, Moreira Mda C, Filho GB, Schijman AG, et al: Genetic profiling of Trypanosoma cruzi directly in infected tissues using nested PCR of polymorphic microsatellites. Int J Parasitol 2008, 38:839-850.

11. Valadares HMS: Análises populacionais em Trypanosoma cruzi baseadas em microssatélites polimórfios de DNA. Universidade Federal de Minas Gerais, Biochemistry and Immunology 2007. 
12. Souto RP, Fernandes O, Macedo AM, Campbell DA, Zingales B: DNA markers define two major phylogenetic lineages of Trypanosoma cruzi. Mol Biochem Parasitol 1996, 83:141-152.

13. Souto RP, Zingales B: Sensitive detection and strain classification of Trypanosoma cruzi by amplification of a ribosomal RNA sequence. Mol Biochem Parasitol 1993, 62:45-52.

14. Campbell DA, Westenberger SJ, Sturm NR: The determinants of Chagas disease: connecting parasite and host genetics. Curr Mol Med 2004, 4:549-562.

15. Miles MA, Llewellyn MS, Lewis MD, Yeo M, Baleela R, Fitzpatrick S, Gaunt MW, Mauricio IL: The molecular epidemiology and phylogeography of Trypanosoma cruzi and parallel research on Leishmania: looking back and to the future. Parasitology 2009, 136:1509-1528.

16. Revollo S, Oury B, Laurent JP, Barnabe C, Quesney V, Carriere V, Noel S, Tibayrenc M: Trypanosoma cruzi: impact of clonal evolution of the parasite on its biological and medical properties. Exp Parasitol 1998, 89:30-39.

17. Andrade LO, Machado CR, Chiari E, Pena SD, Macedo AM: Trypanosoma cruzi: role of host genetic background in the differential tissue distribution of parasite clonal populations. Exp Parasitol 2002, 100:269-275.

18. Burgos JM, Begher SB, Freitas JM, Bisio M, Duffy T, Altcheh J, Teijeiro R, Lopez Alcoba H, Deccarlini F, Freilij H, et al: Molecular diagnosis and typing of Trypanosoma cruzi populations and lineages in cerebral Chagas disease in a patient with AIDS. Am J Trop Med Hyg 2005, 73:1016-1018

19. Rodrigues CM, Valadares HM, Francisco AF, Arantes JM, Campos CF, TeixeiraCarvalho A, Martins-Filho OA, Araujo MS, Arantes RM, Chiari E, et al: Coinfection with different Trypanosoma cruzi strains interferes with the host immune response to infection. PLoS Negl Trop Dis 2010, 4:e846.

20. Salazar A, Schijman AG, Triana-Chavez O: High variability of Colombian Trypanosoma cruzi lineage I stocks as revealed by low-stringency single primer-PCR minicircle signatures. Acta Trop 2006, 100:110-118.

21. Vago AR, Macedo AM, Oliveira RP, Andrade LO, Chiari E, Galvao LM, Reis D, Pereira ME, Simpson AJ, Tostes S, Pena SD: Kinetoplast DNA signatures of Trypanosoma cruzi strains obtained directly from infected tissues. Am J Pathol 1996, 149:2153-2159.

22. Mejia-Jaramillo AM, Arboleda-Sanchez S, Rodriguez IB, Cura C, Salazar A, Del Mazo J, Triana-Chavez O, Schijman AG: Geographical clustering of Trypanosoma cruzi I groups from Colombia revealed by low-stringency single specific primer-PCR of the intergenic regions of spliced-leader genes. Parasitol Res 2009, 104:399-410.

23. Vago AR, Andrade LO, Leite AA, d'Avila Reis D, Macedo AM, Adad SJ, Tostes $S \mathrm{Jr}$, Moreira MC, Filho GB, Pena SD: Genetic characterization of Trypanosoma cruzi directly from tissues of patients with chronic Chagas disease: differential distribution of genetic types into diverse organs. Am J Pathol 2000, 156:1805-1809.

24. Pena SD, Barreto G, Vago AR, De Marco L, Reinach FC, Dias Neto E, Simpson AJ: Sequence-specific "gene signatures" can be obtained by PCR with single specific primers at low stringency. Proc Natl Acad Sci U S A 1994, 91:1946-1949.

25. Baptista C, Schubach AO, Madeira MF, Leal CA, Pires MQ, Oliveira FS, Conceicao-Silva F, Rosalino CM, Salgueiro MM, Pacheco RS: Leishmania (Viannia) braziliensis genotypes identified in lesions of patients with atypical or typical manifestations of tegumentary leishmaniasis: evaluation by two molecular markers. Exp Parasitol 2009, 121:317-322.

26. Barreto G, Vago AR, Ginther C, Simpson AJ, Pena SD: Mitochondrial D-loop "signatures" produced by low-stringency single specific primer PCR constitute a simple comparative human identity test. Am J Hum Genet 1996, 58:609-616.

27. Bomfim MR, Koury MC: Evaluation of LSSP-PCR for identification of Leptospira spp. in urine samples of cattle with clinical suspicion of leptospirosis. Vet Microbio/ 2006, 118:278-288.

28. Gadiou S, Safarova D, Navratil M: Differentiation of Plum pox virus isolates by single-strand conformation polymorphism and low-stringency single specific primer PCR analysis of HC-Pro genome region. Acta Virol 2009, 53:53-56.

29. Marquez DS, Ramirez LE, Moreno J, Pedrosa AL, Lages-Silva E: Trypanosoma rangeli: RAPD-PCR and LSSP-PCR analyses of isolates from southeast Brazil and Colombia and their relation with KPI minicircles. Exp Parasitol 2007, 117:35-42.
30. Stamenkovic G, Guduric J, Velickovic Z, Skerl V, Krtolica K, Veljkovic E, Dimitrijevic $B$ : Analysis of $5^{\prime}$ non-coding region in hepatitis $C$ virus by single-strand conformation polymorphism and low-stringency single specific primer PCR. Clin Chem Lab Med 2001, 39:948-952.

31. Gomes MA, Silva EF, Macedo AM, Vago AR, Melo MN: LSSP-PCR for characterization of strains of Entamoeba histolytica isolated in Brazil. Parasitology 1997, 114(Pt 6):517-520.

32. Villa LL, Caballero OL, Levi JE, Pena SD, Simpson AJ: An approach to human papillomavirus identification using low stringency single specific primer PCR. Mol Cell Probes 1995, 9:45-48.

33. de Oliveira FS, Valete-Rosalino CM, Schubach Ade O, Pacheco Rda S: kDNA minicircle signatures of Leishmania (Viannia) braziliensis in oral and nasal mucosa from mucosal leishmaniasis patients. Diagn Microbiol Infect Dis 2010, 66:361-365.

34. Sturm NR, Degrave W, Morel C, Simpson L: Sensitive detection and schizodeme classification of Trypanosoma cruzi cells by amplification of kinetoplast minicircle DNA sequences: use in diagnosis of Chagas' disease. Mol Biochem Parasitol 1989, 33:205-214.

35. Andrade LO, Machado CR, Chiari E, Pena SD, Macedo AM: Differential tissue distribution of diverse clones of Trypanosoma cruzi in infected mice. Mol Biochem Parasitol 1999, 100:163-172.

36. Santos FR, Epplen JT, Pena SD: Testing deficiency paternity cases with a Y-linked tetranucleotide repeat polymorphism. EXS 1993, 67:261-265.

37. Nunes ACP, Pena SDJ: DNA-POP Program for Playstation Study of DNA fingerprints. Belo Horizonte: Universidade Federal de Minas Gerais; 1993.

38. Nei M, Li WH: Mathematical model for studying genetic variation in terms of restriction endonucleases. Proc Natl Acad Sci U S A 1979, 76:5269-5273.

39. Van de Peer $Y$, De Wachter R: TREECON for Windows: a software package for the construction and drawing of evolutionary trees for the Microsoft Windows environment. In Comput Appl Biosci 1994, 10:569-570. 569-570.

40. Brito CM, Lima MM, Sarquis O, Pires MQ, Coutinho CF, Duarte R, Pacheco RS: Genetic polymorphism in Trypanosoma cruzi I isolated from Brazilian Northeast triatomines revealed by low-stringency single specific primerpolymerase chain reaction. Parasitol Res 2008, 103:1111-1117.

41. Lages-Silva E, Ramirez LE, Pedrosa AL, Crema E, da Cunha Galvao LM, Junho Pena SD, Macedo AM, Chiari E: Variability of kinetoplast DNA gene signatures of Trypanosoma cruzi II strains from patients with different clinical forms of Chagas' disease in Brazil. J Clin Microbiol 2006, 44:2167-2171

42. Braga MS, Lauria-Pires L, Arganaraz ER, Nascimento RJ, Teixeira AR: Persistent infections in chronic Chagas' disease patients treated with anti-Trypanosoma cruzi nitroderivatives. Rev Inst Med Trop Sao Paulo 2000, 42:157-161.

43. Rodriguez IB, Botero A, Mejia-Jaramillo AM, Marquez EJ, Ortiz S, Solari A, Triana-Chavez O: Transmission dynamics of Trypanosoma cruzi determined by low-stringency single primer polymerase chain reaction and southern blot analyses in four indigenous communities of the Sierra Nevada de Santa Marta, Colombia. Am J Trop Med Hyg 2009, 81:396-403.

44. Botero LA, Mejia AM, Triana O: Biological and genetic characterization of two Colombian clones of Trypanosoma cruzi groups I and II. Biomedica 2007, 27(Suppl 1):64-74.

45. Mejia AM, Triana O: Genetic variability of Trypanosoma cruzi in blood and organs of infected mice determined by LSSP-PCR. Biomedica 2005, 25:76-86.

46. Freitas JM, Andrade LO, Pires SF, Lima R, Chiari E, Santos RR, Soares M, Machado CR, Franco GR, Pena SD, Macedo AM: The MHC gene region of murine hosts influences the differential tissue tropism of infecting Trypanosoma cruzi strains. PLoS One 2009, 4:e5113.

47. Lages-Silva E, Ramirez LE, Silva-Vergara ML, Chiari E: Chagasic meningoencephalitis in a patient with acquired immunodeficiency syndrome: diagnosis, follow-up, and genetic characterization of Trypanosoma cruzi. Clin Infect Dis 2002, 34:118-123.

\section{doi:10.1186/1756-0500-6-174}

Cite this article as: Segatto et al.: LSSP-PCR of Trypanosoma cruzi: how the single primer sequence affects the kDNA signature. BMC Research Notes 2013 6:174. 